\title{
Dynamics of thraustochytrid protists in the water column of the Arabian Sea
}

\author{
Seshagiri Raghukumar*, Nagappa Ramaiah, Chandralata Raghukumar \\ Biological Oceanography Division, National Institute of Oceanography, Dona Paula, Goa 403 004, India
}

\begin{abstract}
Thraustochytrids, a group of osmoheterotrophic chromistan protists are ubiquitous in the sea. However, little is known of their ecological role, particularly in oceanic waters. To obtain an insight into their dynamics in this realm, we investigated thraustochytrids and bacteria in the water column, up to $2000 \mathrm{~m}$ in the central Arabian Sea. Four seasons, namely the end of the southwest summer monsoon (September/October 1993), the summer pre-monsoon (April/May 1994), the end of the northeast winter monsoon (February/March 1995) and the peak period of the southwest monsoon (July/August 1995) were studied. Thraustochytrids were estimated using the acriflavine direct detection method (AfDD) and bacteria by the acridine orange direct counts (AODC). Thraustochytrids were present in substantial numbers throughout the $150 \mathrm{~m}$ water column in all the stations investigated during the end of the biologically productive summer and winter monsoons $\left(0\right.$ to $1313 \times 10^{3}$ and 3.7 to $183 \times 10^{3}$ cells s $^{-1}$ water respectively). Their populations in the upper $150 \mathrm{~m}$ were positively related to bacteria and particulate organic matter during these 2 periods, the relationship being significant during the end of the winter monsoon. They were infrequent during the low productive summer pre-monsoon period (present in $<29 \%$ of the total 41 samples), a period of high bacterial abundance, as well as in the peak-productive southwest summer monsoon (present in 10 of 19 samples). Vertical distribution was seasonally variable. Thraustochytrids were regularly detected in the Arabian Sea oxygen minimum zone (OMZ) at 200 to $1000 \mathrm{~m}$. Similar to the upper $150 \mathrm{~m}$, thraustochytrids below $200 \mathrm{~m}$ were least frequent in the summer pre-monsoon (present in $49 \%$ of samples), although high numbers, up to $266 \times 10^{3} \mathrm{l}^{-1}$ were found at $1000 \mathrm{~m}$ in 1 station. Their numbers in the OMZ ranged from 0 to $38 \times 10^{3} \mathrm{l}^{-1}$ during the end of the summer and winter monsoons. Both thraustochytrids and bacteria showed a distinct peak at 250 to $500 \mathrm{~m}$ in the OMZ during these 2 seasons. Dense populations of thraustochytrids were detected even at depths up to $2000 \mathrm{~m}$. We hypothesise that seasonal increases of thraustochytrid populations are related to particles following phytoplankton degradation at the end of the biologically productive seasons. Our estimates suggest that during the 3 seasons, maximum thraustochytrid $C$ biomass reached values ranging from 36 to $217 \%$ of bacterial $C$ biomass in the upper $150 \mathrm{~m}$ and 34.5 to $56 \%$ of bacterial C biomass between 200 and $2000 \mathrm{~m}$.
\end{abstract}

KEY WORDS: Thraustochytrids $\cdot$ Abundance $\cdot$ Arabian Sea $\cdot$ Seasonal distribution

\section{INTRODUCTION}

Recent years have seen several publications on the widespread and abundant occurrence of thraustochytrids, a group of fungoid protists belonging to the Phylum Heterokonta of the Kingdom Chromista (Porter 1990, Cavalier-Smith et al. 1994, Raghukumar

*E-mail: raghu@csnio.ren.nic.in
1996). They have been reported from a wide variety of marine habitats including the water column of the Atlantic, the North Sea, Arabian Sea and coastal waters of Japan (Gaertner \& Raghukumar 1980, Moss 1986, Porter 1990, Raghukumar et al. 1990, 2000, Raghukumar \& Schaumann 1993, Raghukumar 1996, Naganuma et al. 1998, Kimura et al. 1999). Thraustochytrids are osmoheterotrophic and produce extracellular enzymes capable of breaking down several complex or- 
ganic substrates (Bahnweg 1970a,b, Raghukumar et al. 1994, Bremer \& Talbot 1995). In addition, they are high in polyunsaturated fatty acids that are essential nutrients for crustaceans (Findlay et al. 1986, Harrison 1990). These facts suggest that these protists may play an important role in mineralization processes and food web dynamics in the open water column. An essential prerequisite to understanding their role in ecological processes is to obtain reasonably accurate quantitative data on their populations in different seasons with relation to other ecologically important parameters. Although attempts have been made to quantify thraustochytrids earlier in the North Sea (Gaertner \& Raghukumar 1980, Raghukumar \& Gaertner 1980), the results were based on culture methods that would yield much lower values than direct detection techniques. Besides, these studies did not relate information on thraustochytrids to other parameters. Raghukumar \& Schaumann (1993) developed and applied a direct detection method to quantify thraustochytrids in the North Sea, proving that a high abundance of up to $5.4 \times$ $10^{6}$ thraustochytrid cells $\mathrm{g}^{-1}$ phytoplankton detritus occurred in these waters. Using this technique, Naganuma et al. (1998) demonstrated dense populations of thraustochytrids in Japanese coastal waters. Subsequently, Kimura et al. (1999) showed that the carbon biomass of thraustochytrids in coastal waters of Japan could amount to nearly $42 \%$ of the bacterial biomass. However, their presence in the water column of open oceans is poorly understood. Are thraustochytrids also abundant in offshore waters? If so, are they restricted to areas and periods of high biological production, or can they also subsist in oligotrophic waters? Are thraustochytrids common in the deeper parts of oceanic water column?

The Arabian Sea offers an ideal setting for addressing these questions. It is one of the most productive waters in the world (Madhupratap \& Parulekar 1993, Smith et al. 1998). It is also an area with many unique features. Seasonally reversing wind-driven circulation patterns, prevalence of the southwest or summer monsoon during June to September, the northeast or winter monsoon between November and February, and the summer pre-monsoon period in April and May bring about drastic seasonal changes in the physics, chemistry and biological processes of the region (Burkill et al. 1993, Shetye et al. 1994, Madhupratap et al. 1996, Morrison et al. 1998). Total carbon dioxide resulting from microbial activities is higher and dissolved organic carbon lower in the northern Arabian Sea compared to the southern regions (Kumar et al. 1990). The intermediate waters constitute an oxygen minimum zone (OMZ) that is one of the most intense denitrification zones among the world oceans (Naqvi 1994). The Arabian Sea is also a major source of atmospheric carbon dioxide (Sarma et al. 1999). In this paper, we present information on the abundance of thraustochytrids in offshore as well as coastal waters of the Arabian Sea during different seasons, up to a depth of $2000 \mathrm{~m}$. In addition, we have also made an attempt to relate thraustochytrid data to bacteria, chlorophyll and particulate organic carbon (POC).

\section{MATERIALS AND METHODS}

These studies were carried out during the Joint Global Ocean Flux Studies (JGOFS-India) cruises between 1993 and 1996.

Location of the sampling stations in which thraustochytrids were studied is given in Fig. 1. The work was carried out during 4 cruises on board ORV 'Sagar Kanya', as follows: (1) Cruise \# SK 87 during the late summer or southwest monsoon in September/October 1993, 3 stations; (2) Cruise \# SK 91 during the summer pre-monsoon in April/May 1994, 6 stations; (3) Cruise \# SK 99 during the late winter or northeast monsoon in February/March 1995, 7 stations; and (4) Cruise \# SK 104 during the peak summer or southwest monsoon in July/August 1995, 5 stations. Water samples from 0 to $150 \mathrm{~m}$ depths were collected for all the stations. Samples were also obtained from depths below $200 \mathrm{~m}$ at some stations. All samplings were made using a CTD

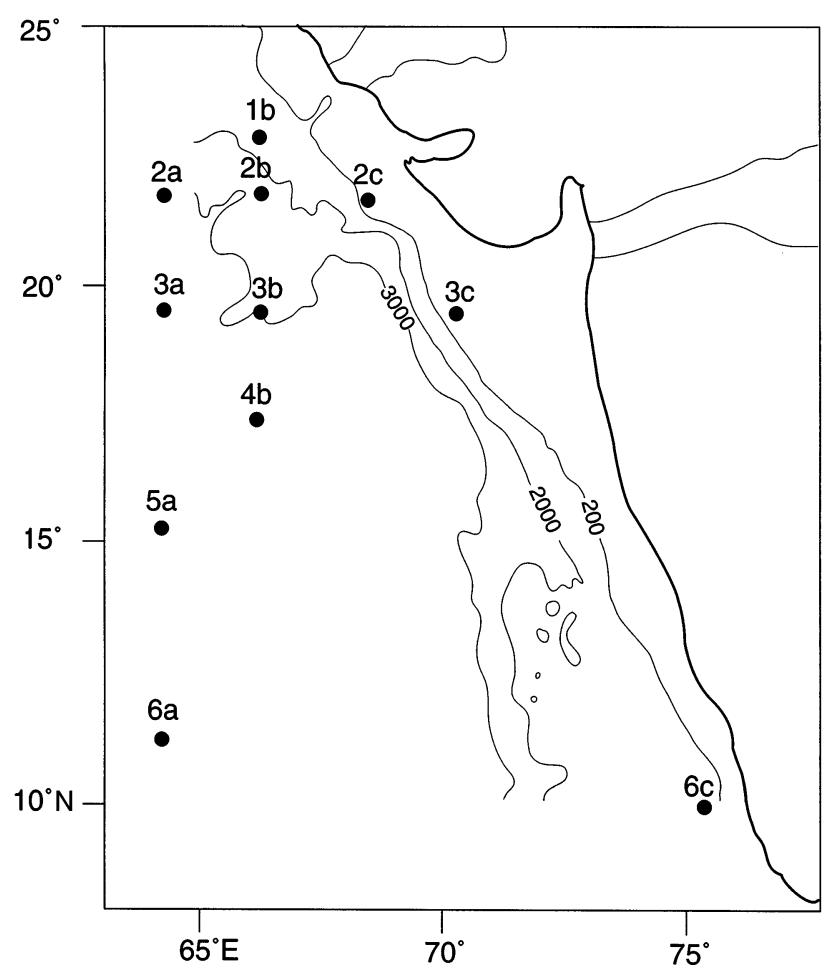

Fig. 1. Location of sampling stations in the Arabian Sea studied during the 4 cruises 
rosette sampler, employing 2.51 Niskin samplers. All water samples $(100 \mathrm{ml})$ were immediately fixed in $3 \%$ formaldehyde and stored in a refrigerator at $10^{\circ} \mathrm{C}$ till the end of the cruise. Thraustochytrids in the water samples were analysed immediately in the laboratory on shore. Between 15 and $50 \mathrm{ml}$ of the water samples were filtered over $25 \mathrm{~mm}$ black Nuclepore polycarbonate filters of $0.8 \mu \mathrm{m}$ pore diameter and stained, following the acriflavine direct detection method (AfDD) of Raghukumar \& Schaumann (1993). The only deviation from the method was rinsing with filter-sterilised sea water, instead of $70 \%$ isopropyl alcohol following staining. Up to 25 microscope fields were scanned using a $100 \times$ oil immersion objective and a $10 \times$ eyepiece under a BX2 Olympus epifluorescence microscope. Thraustochytrid cells were detected by their characteristic orange-red cell walls and blue-green cell contents (Raghukumar \& Schaumann 1993). Whenever no cells were detected in 25 microscope fields, up to 75 fields were scanned until at least 1 was detected. This corresponded to a detection limit of 3700 cells $1^{-1}$, and values below this are indicated as 0 in our results. Total number of thraustochytrids $\mathrm{l}^{-1}$ was calculated following the formula for total counts of bacteria given in Parsons et al. (1984).

In addition to using the AfDD, thraustochytrids were also enumerated for many stations, using the same water samples, by the MPN culture method of Gaertner (1968). Aliquots of 10, 5, 2.5 and $1.25 \mathrm{ml}$ of sea water samples were added to flat-bottomed, $15 \mathrm{ml}$ screw-capped tubes. In sets with less than $10 \mathrm{ml}$, the final volume was adjusted to $10 \mathrm{ml}$ using appropriate amounts of sterile sea water. Sterile pine pollen were then added to the dilution tubes. All the tubes were microscopically examined for the growth of thraustochytrids on the pollen within 1 mo after isolation. The total number of thraustochytrids $\mathrm{l}^{-1}$ was calculated using the Thomas' formula for MPN technique (Anonymous 1981).

Total number of bacteria was estimated using the AODC method (Parsons et al. 1984). Values of chlorophyll and particulate organic carbon (POC) were obtained from NIO database.

Thraustochytrid biomass was calculated using a value of $20.6 \times 10^{-12} \mathrm{~g} \mathrm{cell}^{-1}$ of $5 \mu \mathrm{m}$ diameter. This is based on values of Kimura et al. (1999) for an average size of $10 \mu \mathrm{m}$ for thraustochytrids. Our field observations suggest that such large cells are seldom found in oceanic samples. Thraustochytrid cells range in size from $2.0 \mu \mathrm{m}$ in the case of zoospores to between 5.0 and $20.0 \mu \mathrm{m}$ in the case of mature thalli, especially in cultures. Our values, therefore, are calculated for a more reasonable average size of $5 \mu \mathrm{m}$ diameter. Bacterial biomass was based on a value of $30.2 \times 10^{-15} \mathrm{~g}$ per bacterial cell (Fukuda et al. 1998).

\section{RESULTS}

Thraustochytrid and bacterial populations in the upper $150 \mathrm{~m}$ are presented for the late summer monsoon during September/October 1993, the summer pre-monsoon period of April/May 1994 and the late winter monsoon period during February/March 1995 (Figs. 2, 3 \& 4). In addition, thraustochytrid and bacterial abundance below $200 \mathrm{~m}$ are also depicted for many stations during these cruises.

During the late summer monsoon, thraustochytrids were detected using the AfDD technique in all the 3 stations sampled and at most depths in the upper $150 \mathrm{~m}$ of the water column (14 out of 15 samples, 93\%) (Fig. 2). Their numbers varied from 0 to $1313 \times 10^{3}$ cells $\mathrm{l}^{-1}$ water. The highest numbers were detected at $20 \mathrm{~m}$ in the northernmost station of $21^{\circ} \mathrm{N}, 66^{\circ} \mathrm{E}$ (Stn $2 \mathrm{~b}$ ), where they were associated with a very high abundance of mucus-like particles. Recovery of thraustochytrids using the pine pollen baiting method was greater, however, in the southernmost station of $17^{\circ} \mathrm{N}$, $66^{\circ} \mathrm{E}$ (Stn $4 \mathrm{~b}$; Table 1). Culturing technique yielded only 0 to 1000 cells $\mathrm{l}^{-1}$ during this cruise (Table 1 ). Higher numbers of thraustochytrids were observed within the upper $50 \mathrm{~m}$. The distribution trend of thraustochytrids in the upper $150 \mathrm{~m}$ water column closely resembled that of the bacteria, which ranged from 0.3 to $1.5 \times 10^{9} \mathrm{l}^{-1}$. Numbers of free and attached thraustochytrids were separately counted during this cruise in the upper $150 \mathrm{~m}$. One-way analysis of variance (oneway ANOVA) indicated that the differences in numbers between the 2 were not statistically significant $(\mathrm{df}=28 ; F=0.52031 ; \mathrm{p}=0.477)$. Sixteen out of 23 samples collected below $200 \mathrm{~m}(70 \%)$ also yielded thraustochytrids during the late summer monsoon. Thraustochytrids ranged from 0 to $36 \times 10^{3}$ cells $1^{-1}$ at these intermediate depths, while bacteria ranged from 0.01 to $0.65 \times 10^{9}$ cells $1^{-1}$ (Fig. 2). The highest number of thraustochytrids below $200 \mathrm{~m}$ was observed at $1750 \mathrm{~m}$

Table 1. Number of thraustochytrids $\mathrm{l}^{-1}$ in the water column of the Arabian Sea during September/October 1993 (Cruise SK 87), as estimated by the MPN pine pollen baiting method. (nd: not determined)

\begin{tabular}{|lcc|}
\hline \multirow{2}{*}{ Depth $(\mathrm{m})$} & \multicolumn{2}{c|}{ Latitude, Longitude } \\
& $17^{\circ} \mathrm{N}, 66^{\circ} \mathrm{E}_{\text {; }}$ Stn $4 \mathrm{~b}$ & $19^{\circ} \mathrm{N}, 66^{\circ} \mathrm{E}$; Stn $3 \mathrm{~b}$ \\
\hline 0 & 0 & nd \\
20 & 1000 & nd \\
45 & 234 & 99 \\
100 & 167 & nd \\
150 & 31 & 115 \\
250 & 34 & 29 \\
1200 & 19 & nd \\
\hline
\end{tabular}


\# 2b

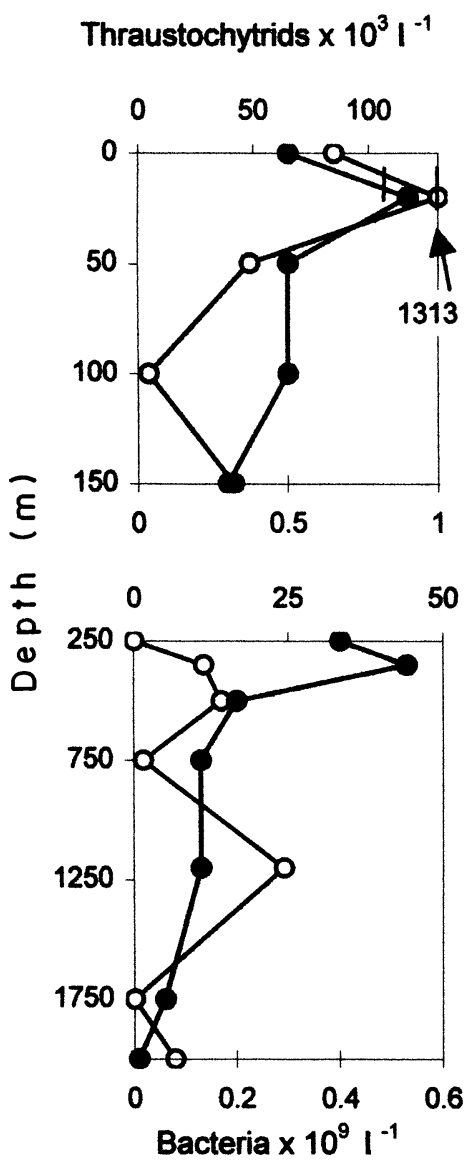

\# 3b
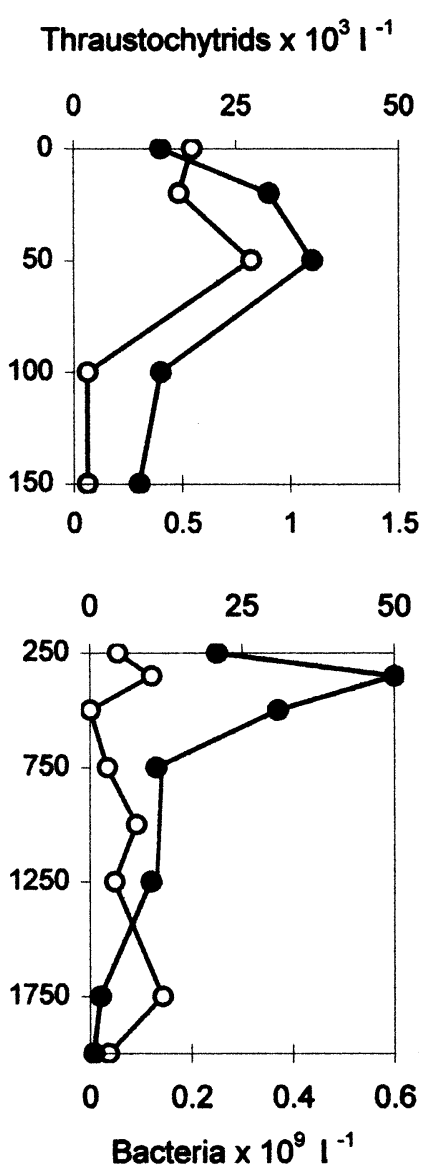

\# 4b

Thraustochytrids $\times 10^{3} \mathrm{I}^{-1}$
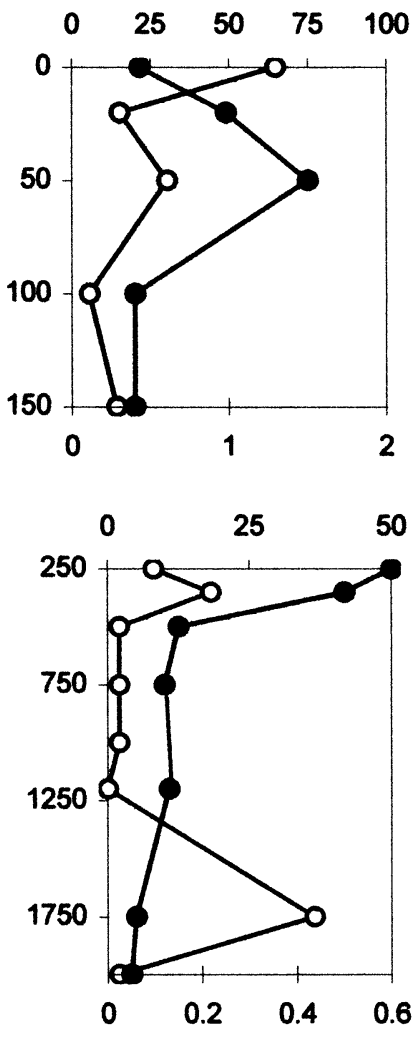

Bacteria $\times 10^{9} \mathrm{I}^{-1}$

Fig. 2. Abundance of thraustochytrids (0) and bacteria $(\bullet)$ in the water column at 3 stations, during the late summer monsoon period of September/October 1993

in the southernmost station (Stn $4 \mathrm{~b}$ ). Both thraustochytrids and bacteria showed a distinct peak between 250 and $500 \mathrm{~m}$ at all 3 stations. Thraustochytrids also revealed a second, prominent peak at around $1750 \mathrm{~m}$ in 2 stations. This was not seen in the case of bacteria. Generally, both groups of organisms showed a similar trend of distribution at these depths (Fig. 2). Water samples below $150 \mathrm{~m}$ were cultured during this cruise and confirmed the presence of thraustochytrids up to $1200 \mathrm{~m}$ depth (Table 1).

Thraustochytrids were least frequent during the summer pre-monsoon, and were detected in only 12 out of 41 samples $(29 \%)$ in the upper $150 \mathrm{~m}$, collected from the total 6 stations sampled. Their populations

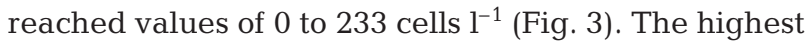
numbers occurred at $80 \mathrm{~m}$ in the station $19^{\circ} \mathrm{N}, 64^{\circ} \mathrm{E}$ (Stn 3a). This station also revealed higher numbers of thraustochytrids in the upper $150 \mathrm{~m}$ than the others. Peaks of thraustochytrid populations during this period generally occurred at 0 or $100 \mathrm{~m}$ and they were seldom present in the subsurface layers. They were not detected during this cruise using the culture methods. Thraustochytrids were also infrequent below $200 \mathrm{~m}$ during the summer pre-monsoon (Fig. 3). Only 17 out of 35 samples $(49 \%)$ revealed the presence of thraustochytrids with numbers of 0 to $266 \times 10^{3} \mathrm{l}^{-1}$. The highest density occurred at $1000 \mathrm{~m}$ at the northernmost station of $21^{\circ} \mathrm{N}, 64^{\circ} \mathrm{E}$ (Stn 2a). This was the highest number of thraustochtytrids recorded in the OMZ for all 3 seasons studied. In contrast to thraustochytrids, bacterial numbers were very high during this period ( 0.25 to $0.81 \times 10^{9} \mathrm{l}^{-1}$ in the upper $150 \mathrm{~m}$ and 0.05 to $0.65 \times 10^{9} \mathrm{l}^{-1}$ below $200 \mathrm{~m}$ ). Distribution of thraustochytrids and bacteria were often negatively related. Both bacteria and thraustochytrids revealed peaks between 250 and $500 \mathrm{~m}$.

Thraustochytrids were present in all 7 stations sampled and in the entire water column up to $150 \mathrm{~m}$ during the late winter monsoon (Fig. 4). All 31 samples (100\%) yielded thraustochytrids. They ranged from 3.7 to $183 \times 10^{3}$ cells l$^{-1}$. The highest values occurred in the southern stations of the central Arabian Sea, $11^{\circ} \mathrm{N}$, 
\#1b

Thraustochytrids $\times 10^{3} \mathrm{I}^{-1}$

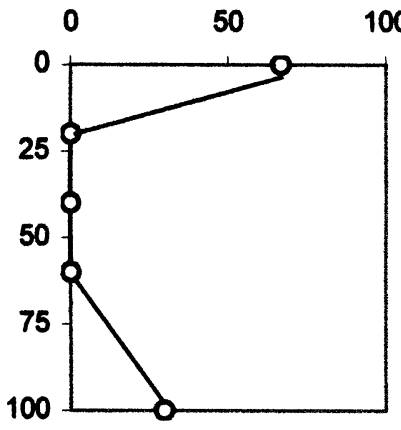

\# 2a

Thraustochytrids $\times 10^{3} \mathrm{I}^{-1}$

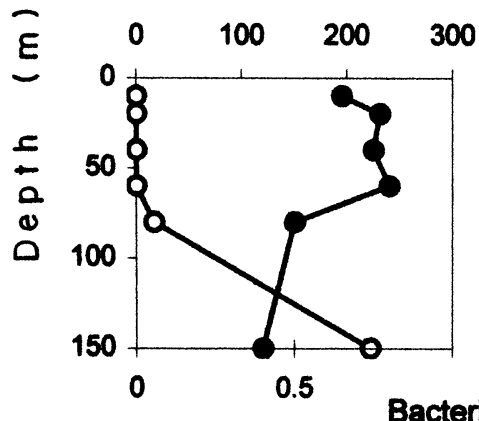

Bacteria $\times 10^{9} 1^{-1}$

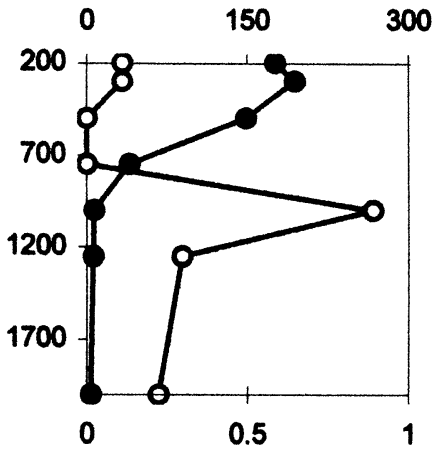

Bacteria $\times 10^{9} 1^{-1}$
\# 3a

Thraustochytrids $\times 10^{3} \mathrm{I}^{-1}$
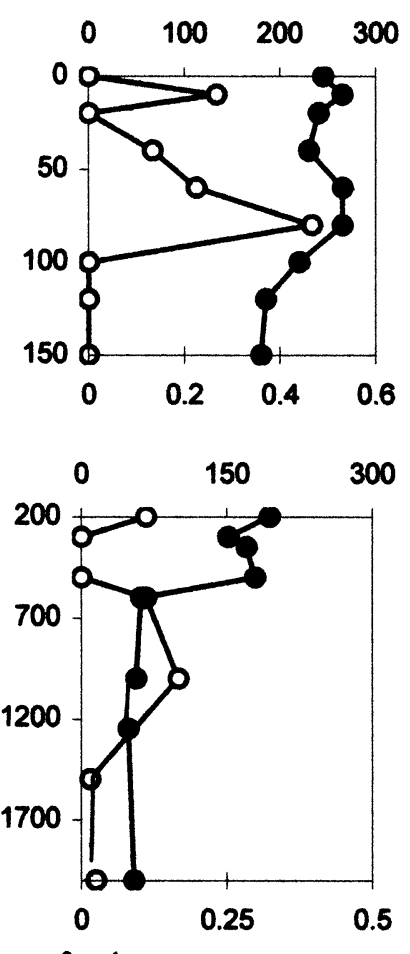

300

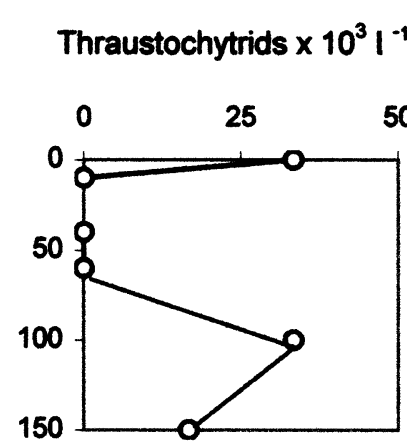

\#5a

Thraustochytrids $\times 10^{3} \mathrm{I}^{-1}$
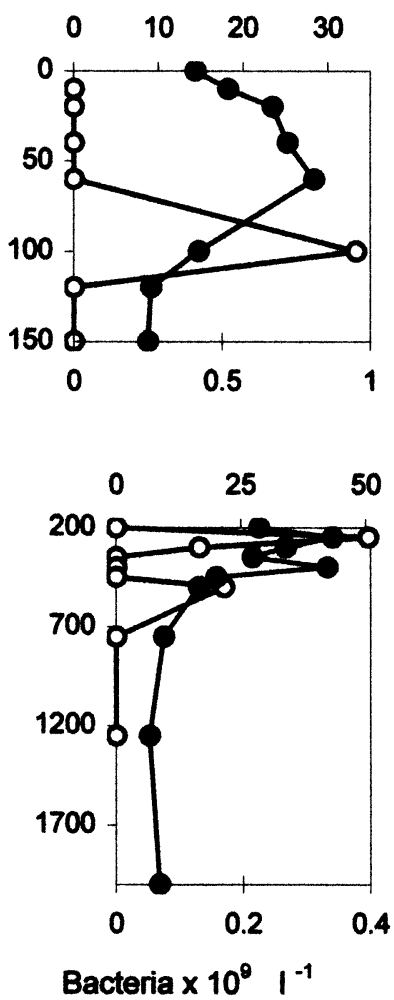

\#6a

Thraustochytrids $\times 10^{3} \mathrm{I}^{-1}$
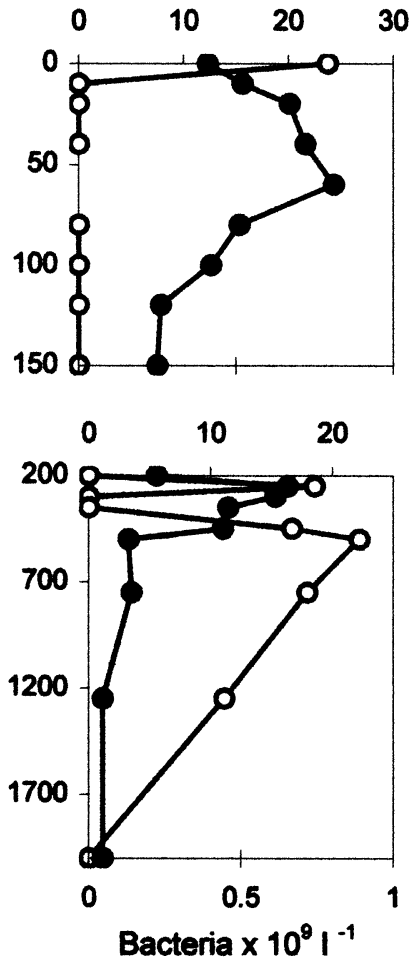

Bacteria $\times 10^{9} \mathrm{I}^{-1}$

Fig. 3. Abundance of thraustochytrids (O) and bacteria (-) in the water column at 6 stations, during the summer pre-monsoon period of April/May 1994 


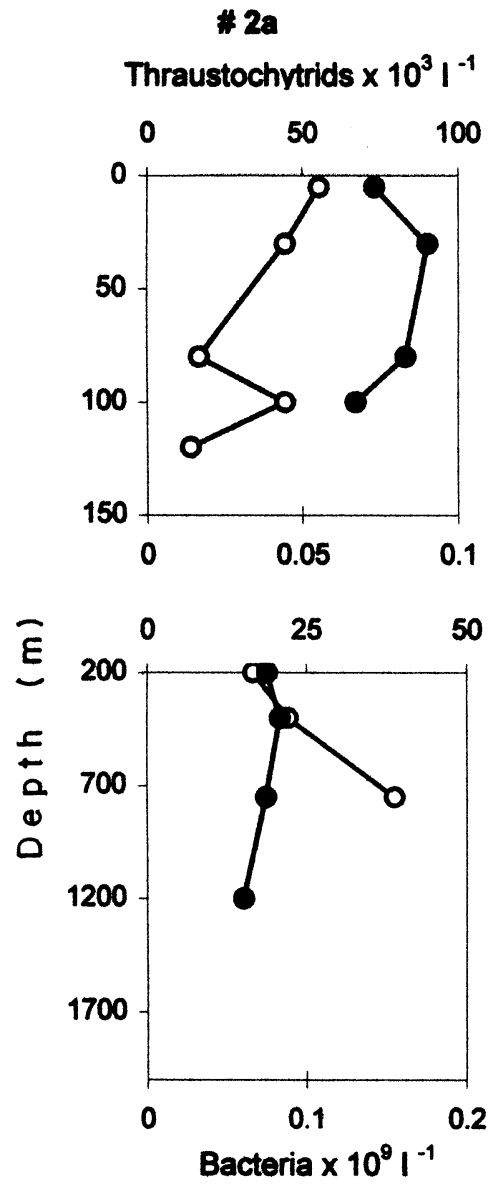

$\# 2 c$

Thraustochytrids $\times 10^{3} \mathrm{I}^{-1}$

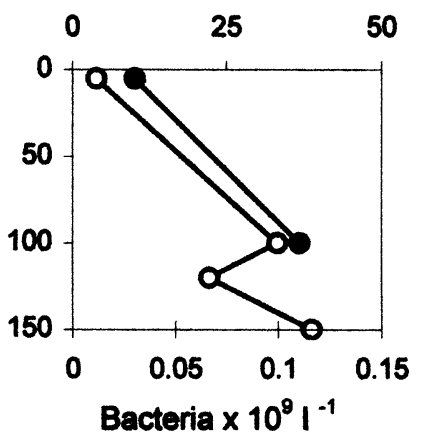

\# 3a

Thraustochytrids $\times 10^{3} \mathrm{I}^{-1}$

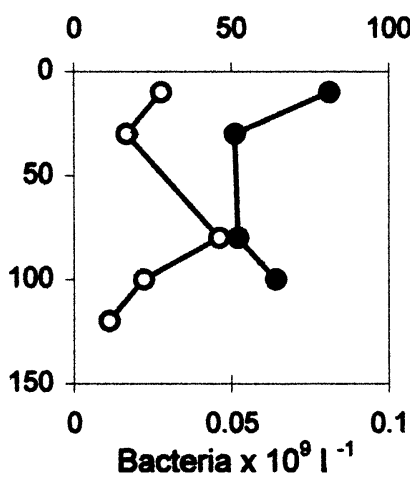

$\# 3 c$

Thraustochytrids $\times 10^{3} 1^{-1}$

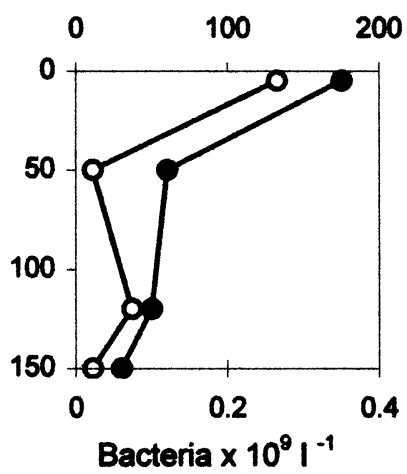

\#6a

Thraustochytrids $\times 10^{3} \mathrm{I}^{-1}$

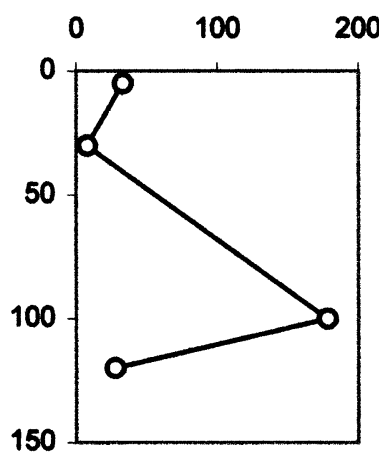

\# 5a

Thraustochytrids $\times 10^{3} 1^{-1}$
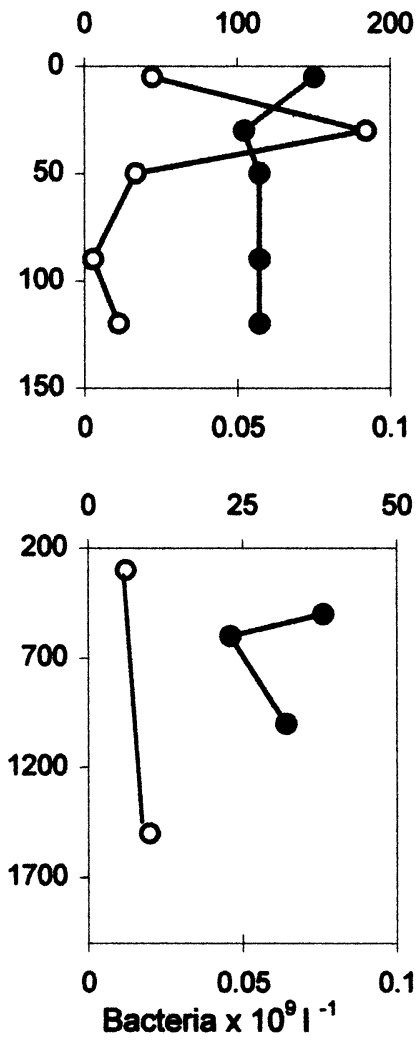

\#6c

Thraustochytrids $\times 10^{3} \mathrm{I}^{-1}$

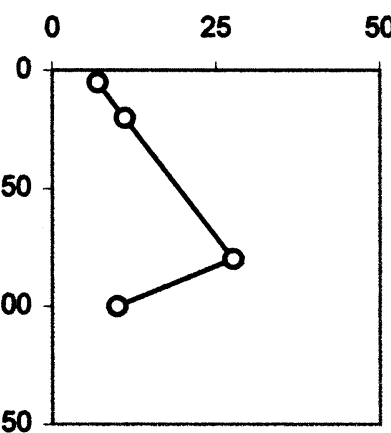

Fig. 4. Abundance of thraustochytrids $(\mathbf{O})$ and bacteria $(\bullet)$ in the water column at 7 stations, during the late winter monsoon period of February/March 1995

$64^{\circ} \mathrm{E}$ (Stn 6a) and $15^{\circ} \mathrm{N}, 64^{\circ} \mathrm{E}$ (Stn 5a) at 100 and $40 \mathrm{~m}$ respectively. The southernmost coastal station, $10^{\circ} \mathrm{N}$, $75^{\circ} 37^{\prime} \mathrm{E}$ (Stn 6c) harboured the least numbers. Pine pollen culturing method yielded only 0 to 300 cells $1^{-1}$ (Table 2). Although bacterial numbers were the lowest during this season compared to the others $(0.03$ to $\left.0.35 \times 10^{9} \mathrm{l}^{-1}\right)$, thraustochytrids and bacteria showed a very similar distribution trend in the upper $150 \mathrm{~m}$ of the water column. Thraustochytrids were also present below $200 \mathrm{~m}$ in all 5 samples from 2 stations examined and ranged from 6 to $38 \times 10^{3}$ cells $\mathrm{l}^{-1}$. Maximum values were present at $750 \mathrm{~m}$ at the northernmost station of $21^{\circ} \mathrm{N}, 64^{\circ} \mathrm{E}$ (Stn 2a, Fig. 4). Bacterial numbers below $200 \mathrm{~m}$ were the lowest for this season compared to the other 2 as seen in the 2 stations studied. They ranged only from 0.046 to $0.083 \times 10^{9}$ cells $1^{-1}$ (Fig. 4 ). 
The upper $150 \mathrm{~m}$ of the water column during the peak summer monsoon period of the southwest monsoon in July/August 1995, yielded thraustochytrids in only 10 out of 19 samples taken from a total of 5 different locations. The highest number was $40 \times 10^{3} \mathrm{l}^{-1}$, which was the lowest seasonal maximum among all 4 seasons. Likewise, thraustochytrids were present in only 5 of 13 samples from the water column between 200 and $1000 \mathrm{~m}$.

Regression analyses were carried out for total thraustochytrids against bacteria, chlorophyll $a$ and particulate organic matter (POC) in the water column up to $150 \mathrm{~m}$, for all the stations in 3 separate cruises (Fig. 5). The relation between bacteria and thrausto-chytrids during the late winter monsoon was statistically significant at $5 \%$. A highly significant relation (at $1 \%$ ) between thraustochytrids and POC was also found during this period. Thraustochytrids were not positively related to any of the 3 parameters during the summer premonsoon. Thraustochytrids and bacteria did not show a positive correlation at depths below $200 \mathrm{~m}$.

\section{DISCUSSION}

The greatest abundance of thraustochytrids that we detected in offshore waters of the Arabian Sea during

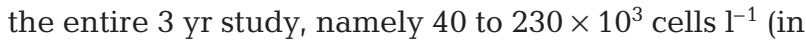
one case, $1313 \times 10^{3} \mathrm{l}^{-1}$ ), equals or often exceeds those observed for coastal waters of Japan by Naganuma et al. (1998) and Kimura et al. (1999), using the same technique as ours. These authors attributed high numbers of thraustochytrids to allochthonous organic matter introduced through riverine inputs. Our study shows that thraustochytrids are abundant even in oceanic waters where they would be dependent on autochthonous organic nutrients. Thraustochytrids are normally isolated with ease from coastal waters using pine pollen, a lignocellulosic bait. However, this was not the case in the present study. This again might indicate that the dense populations of thraustochytrids in oceanic waters are adapted to nutrients that are different from coastal forms which utilise substrates such as lignocellulose.
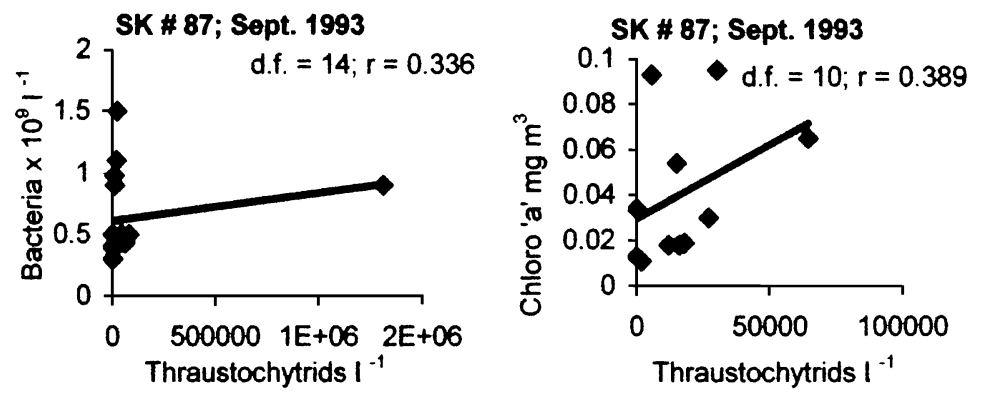

SK \# 91; April I May 1994
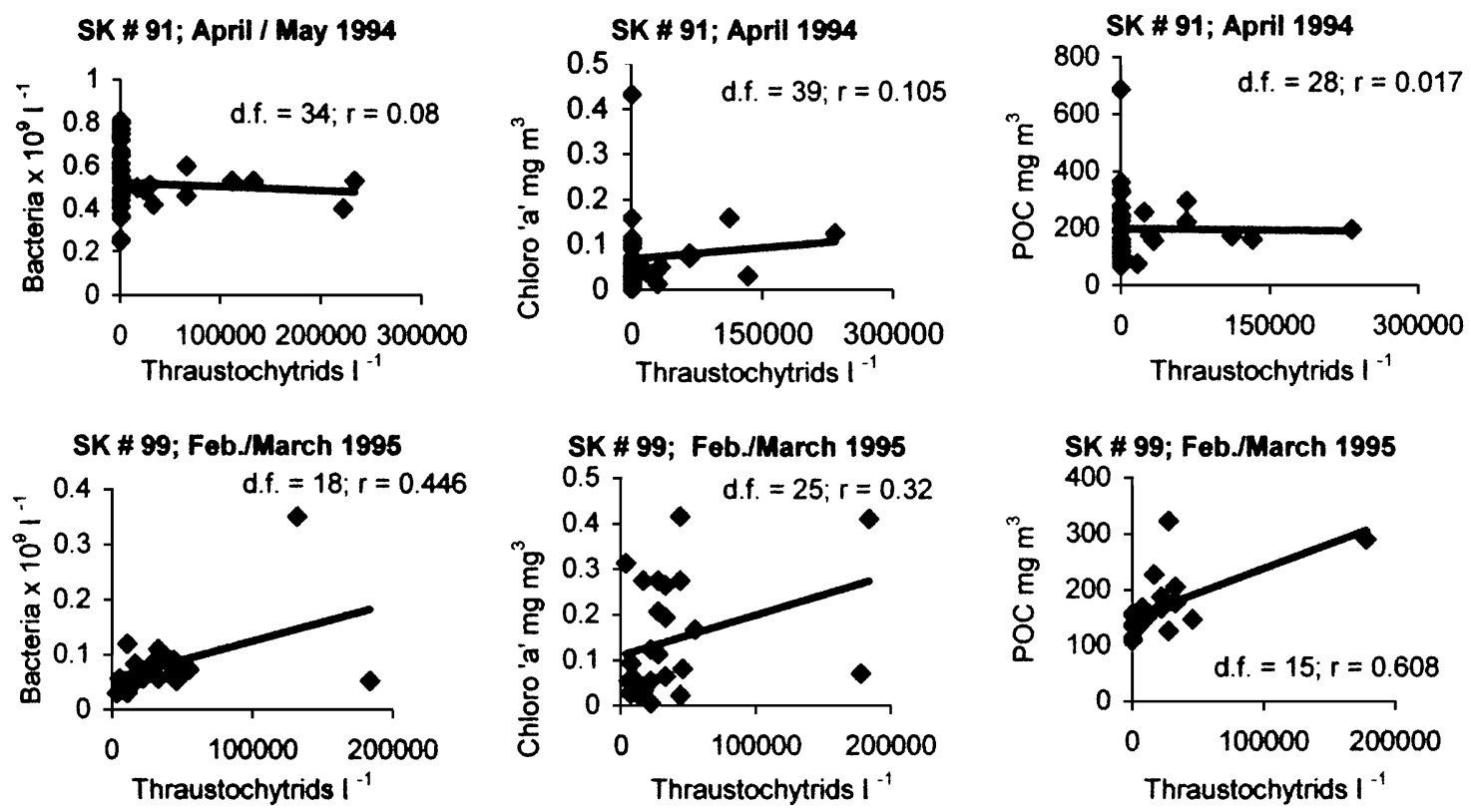

Fig. 5. Regression analyses for thraustochytrid numbers against bacteria, chl $a$ and particulate organic carbon in the upper $150 \mathrm{~m}$ of the water column in the Arabian Sea during 3 cruises 
Table 2. Number of thraustochytrids $1^{-1}$ in the water column in the Arabian Sea during February/March 1995 (Cruise SK 99), as estimated by the MPN pine pollen baiting method. (nd: not determined)

\begin{tabular}{|c|c|c|c|c|c|}
\hline Depth (m) & $11^{\circ} \mathrm{N}, 64^{\circ} \mathrm{E} ; \operatorname{Stn} 6 \mathrm{a}$ & $15^{\circ} \mathrm{N}, 64^{\circ} \mathrm{E} ; \operatorname{Stn} 5 \mathrm{a}$ & $\begin{array}{l}\text { Latitude, Longitude } \\
21^{\circ} \mathrm{N}, 64^{\circ} \mathrm{E}_{;} \text {Stn } 2 \mathrm{a}\end{array}$ & $21^{\circ} \mathrm{N}, 67^{\circ} 50^{\prime} \mathrm{E}_{;} \operatorname{Stn} 2 \mathrm{c}$ & $19^{\circ} \mathrm{N}, 69^{\circ} 50^{\prime} \mathrm{E} ; \operatorname{Stn} 3 \mathrm{c}$ \\
\hline 5 & nd & 146 & 53 & nd & 81 \\
\hline 20 & nd & nd & 155 & nd & nd \\
\hline 30 & 18 & 39 & nd & nd & nd \\
\hline 50 & nd & 18 & 171 & 17 & 65 \\
\hline 80 & 17 & nd & 264 & nd & nd \\
\hline 100 & nd & nd & 300 & 18 & nd \\
\hline 120 & 18 & 18 & nd & 18 & 37 \\
\hline
\end{tabular}

Is thraustochytrid abundance associated with seasons of high primary production? Naganuma et al. (1998) found a positive correlation between thraustochytrids and chlorophyll values in the coastal waters of Japan and suggested that these protists depend to some extent on dissolved organic matter or particulate detritus from phytoplankton. In the present study, no statistically significant relationship between chlorophyll and thraustochytrid abundance was observed (Fig. 5). The summer monsoon period of June to September is a season of extremely high primary productivity in the Arabian Sea, owing to upwelling (Bhattathiri et al. 1996). However, thraustochytrids were present in very low numbers during July/August 1995. Thraustochytrids have also been seldom microscopically observed in association with living phytoplankton (Gaertner 1981). In the case of macroalgae, their culturable populations increase only with senescence and death of the algae (Miller \& Jones 1983, Raghukumar et al. 1992). During a detailed 3 yr study on thraustochytrid populations in the North Sea, Gaertner \& Raghukumar (1980) and Raghukumar \& Gaertner (1980) found very low numbers of these protists during spring blooms of March and April. These studies were based on the Most Probable Number estimations using pine-pollen baiting. This culture technique will not provide accurate values of population densities. However, we assume that this method yields reasonably reliable information on seasonal fluctuations of thraustochytrids.

We believe that thraustochytrids are directly associated with aggregates, particle formation and detritus from phytoplankton, subsequent to their senescence and death rather than with living phytoplankton biomass. Thus, out of the 4 seasons studied, thraustochytrids in the upper $150 \mathrm{~m}$ were most frequent only during the final phases of the summer monsoon, and the late stages of the winter monsoon, attaining substantial populations (Figs. 2 \& 4). The winter monsoon from December to February is a period of convective mixing and winter cooling in the northern Arabian
Sea, leading to cold sea surface temperatures, a deep mixed layer, high values of total carbon dioxide and primary production, elevated chlorophyll values and high levels of total organic carbon (Bhattathiri et al. 1996, Prasanna Kumar \& Prasad 1996, Sarma et al. 1996, Hansell \& Peltzer 1998). The high abundance of thraustochytrids at the end of this period appears to be associated with senescent phytoplankton and detritus formed therefrom. A highly significant positive correlation was also found during this period between POC and thraustochytrids in the upper $150 \mathrm{~m}$ of the water column (Fig. 5). Raghukumar \& Raghukumar (1999) found high numbers of thraustochytrids in faecal pellets of salps collected during this period from the Arabian Sea, suggesting that such particles are important both as nutritional sources and as sites of attachment for thraustochytrids. Similar to the late winter monsoon, the end period of the summer monsoon supported a high abundance of thraustochytrids, although the peak summer monsoon itself did not. Numerous mucoid particles were found at $21^{\circ} \mathrm{N}, 66^{\circ} \mathrm{E}$ (Stn $2 \mathrm{~b}$ ) at the end of the summer monsoon, densely colonised by thraustochytrids $\left(1313 \times 10^{3}\right.$ cells $\left.\mathrm{l}^{-1}\right)$. Using culture methods, Gaertner \& Raghukumar (1980) and Raghukumar \& Gaertner (1980) also found a high abundance of thraustochytrids in the North Sea only at the end of the phytoplankton blooms in the early summer of June.

In support of the above, thraustochytrid frequency of occurrence was very low during the summer premonsoon of April/May, a period characterised by a very shallow mixed layer of about $25 \mathrm{~m}$, low nitrate levels and low phytoplankton biomass and POC (Prasanna Kumar \& Prasad 1996, Bhattathiri et al. 1996). This suggests that their populations are depleted in the absence of particulate detritus. Our observation that the difference between attached and free thraustochytrids during September/October was not statistically significant might appear to be in variance with our conclusion. However, it must be borne in mind that particles such as the transparent exopolymer particles (TEPs) cannot be visualised without proper staining. 
Therefore, many thrausochytrid cells counted as 'free' in our study might, in reality, have been particleborne.

Are thraustochytrids related to bacterial populations? We found a positive correlation between bacteria and thraustochytrids during late summer and winter monsoons (Figs. 2, 4 \& 5), the latter being statistically significant. However, while bacterial abundance was at its seasonal minimum during the late winter monsoon period (see also Ramaiah et al. 1996), thraustochytrids attained high numbers (Fig. 4). Particulate organic matter perhaps served as a major source of carbon for both bacteria and thraustochytrids during these 2 periods. Thraustochytrids and bacteria were somewhat negatively related during the summer premonsoon period, a season of low particle production (Fig. 3). This suggests a competition for the scarcely available particulate matter. Another possibility is the production of phagotrophic amoebae by thraustochytrids that fed on bacteria. Raghukumar (1992) has reported bacterivory by thraustochytrids. However, no field confirmation of this is available. While thraustochytrids may be restricted (or specialised) to utilising POC, bacteria appear to be adept at using both POC, particularly the easily labile transparent exopolymer particles (TEPs) (Ramaiah et al. 2000) as well as dissolved organic carbon (DOC), thus reducing their seasonal dependency on nutritional sources (Azam et al. 1994). During their study on the coastal waters of Japan, Naganuma et al. (1998) found a strong positive correlation between bacteria and thraustochytrids. However, our results indicate that this relation is temporally variable.

Thraustochytrids were regularly found below $150 \mathrm{~m}$. While the presence of thraustochytrids up to depths of $3900 \mathrm{~m}$ are known through the pioneering work of Gaertner (1982), their existence in the intermediate layers assumes special importance in the context of the Arabian Sea. The Arabian Sea is characterised by the presence of an intense oxygen minimum zone in the intermediate layers. At these depths, oxidized nitrogen species are reduced to molecular nitrogen in dissimilatory denitrification processes (Naqvi 1991). The present study not only demonstrates their occurrence in the OMZ of the Arabian Sea, but also reveals distinct peaks in their numbers at depths of 250 to $500 \mathrm{~m}$ (Figs. $2 \& 3$ ). This is also the region of a secondary peak in bacterial numbers (Figs. $2 \& 3$ ). These depths are characterised by a 'nepheloid layer' of relatively high turbidities, anaerobic respiration as evidenced by electron transport system studies (ETS) and high nitrite values (Naqvi et al. 1993). Denitrification under laboratory conditions has been demonstrated only for a few thraustochytrids (Bahnweg 1970a) and they may not play an important role in denitrification processes.
Another interesting feature of thraustochytrids observed in this study is the presence of a secondary peak in their numbers at depths below 800 m (Figs. 2, 3 \& 4). Thus, substantial numbers were found at $1750 \mathrm{~m}$ during late summer monsoon, 1200 to $1250 \mathrm{~m}$ during the summer pre-monsoon and $800 \mathrm{~m}$ during the late winter monsoon. What could be the source of nutrition for thraustochytrids at these depths? Kumar et al. (1998) have shown the presence of transparent exopolymer particles (TEPs) throughout in the water column of the Arabian Sea up to $1000 \mathrm{~m}$ towards the end of the southwest monsoon. These averaged $60 \mathrm{mg}$ alginic acid equivalents (AA eq) $\mathrm{l}^{-1}$ in surface waters

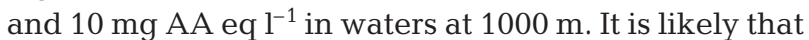
thraustochytrids are associated with such particles. Such an association would imply an important role for these protists in mineralization processes in deep waters. Raghukumar \& Raghukumar (1999) have experimentally shown that thraustochytrids in faecal pellets are capable of tolerating elevated hydrostatic pressures similar to those at depths of $1000 \mathrm{~m}$ and are also capable of producing proteases. The present study provides for the first time direct evidence of a substantial population of thraustochytrids in these depths.

Similar to their seasonal trends in the upper $150 \mathrm{~m}$, thraustochytrid frequencies in the intermediate waters were low also during April/May, although dense populations were detected at certain depths (Fig. 3). The overall low frequencies of thraustochytrids during this time might be related to lower values of TEPs during this non-productive season. However, at these depths thraustochytrids increased in numbers and frequencies towards the northern Arabian Sea (Fig. 3). This coincides with increasing denitrification in the northern stations, resulting in trends of decreasing nitrate and increasing nitrite. However, it is not possible to define any connection between thraustochytrids and denitrification in these depths and further detailed studies are required to address this interesting possibility.

Three papers in recent years have dealt with a substantial biomass of thraustochytrids in the water column. Raghukumar \& Schaumann (1993) found values up to $5.4 \times 10^{6}$ thraustochytrid cells per $\mathrm{g}$ of phytoplankton aggregates of the North Sea. Naganuma et al. (1998) observed up to $5.6 \times 10^{3}$ cells $1^{-1}$ of thraustochytrids in the coastal waters of Japan, their populations often reaching nearly $50 \%$ of biovolume of that of bacteria. Kimura et al. (1999) estimated that the carbon biomass of thraustochytrids in the coastal waters of Japan made up 3.4 to $29 \%$ of the total carbon biomass contributed by these and bacteria. A comparison of the estimated carbon values for thraustochytrids and bacteria in the Arabian Sea during the 3 seasons is presented in Tables $3 \& 4$. Bacterial numbers in different seasons reported by us (see also Ramaiah et al. 1996) 
are similar to values observed by Ducklow (1993). During times when bacterial numbers were high (summer post-monsoon and summer pre-monsoon), thraustochytrid C biomass amounted to 99.0 and $36 \%$ of bacterial biomass, respectively. Thraustochytrid $\mathrm{C}$ biomass was a remarkable $217 \%$ of bacterial biomass during the late winter monsoon period when bacterial numbers were low. Even if restricted to certain seasons and

Table 3. Estimated carbon biomass (in $\mathrm{g}$ ) of thraustochytrids and bacteria $\mathrm{l}^{-1}$ at locations with high thraustochytrid abundance, at 0 to $150 \mathrm{~m}$ in the Arabian Sea, assuming an average size of a thraustochytrid cell as $5.0 \mu \mathrm{m}$ with a carbon content of $20.6 \times 10^{-12}$ cell $^{-1}$. Bacterial carbon values are based on values of $30.2 \times$ $10^{-15} \mathrm{~g}_{\text {carbon }}$ cell $^{-1}$

\begin{tabular}{|lccc|}
\hline & $\begin{array}{c}\text { September/ } \\
\text { October 1993; } \\
\text { Stn 2b; 20 m }\end{array}$ & $\begin{array}{c}\text { April/May 1994; } \\
\text { Stn 3a; } \\
80 \mathrm{~m}\end{array}$ & $\begin{array}{c}\text { February/ } \\
\text { March 1995; } \\
\text { Stn 5a; } 100 \mathrm{~m}\end{array}$ \\
\hline $\begin{array}{l}\text { Maximum numbers } \\
\text { of thraustochytrids } \\
\text { (cells 1 }{ }^{-1} \text { ) }\end{array}$ & $1.3 \times 10^{6}$ & $0.23 \times 10^{6}$ & $0.18 \times 10^{6}$ \\
$\begin{array}{l}\text { Maximum numbers } \\
\text { of bacteria } \\
\text { (cells 1 }{ }^{-1} \text { ) }\end{array}$ & $0.9 \times 10^{9}$ & $0.54 \times 10^{9}$ & $0.057 \times 10^{9}$ \\
$\begin{array}{l}\text { Maximum biomass } \\
\text { of thraustochytrids }\end{array}$ & $26.78 \times 10^{-6}$ & $4.74 \times 10^{-6}$ & $3.71 \times 10^{-6}$ \\
$\begin{array}{l}\text { Maximum biomass } \\
\text { of bacteria } \\
\text { Bacteria:thraustochytrid } \\
\text { biomass } \\
\% \text { of thraustochytrid }\end{array}$ & 1.01 & $13.21 \times 10^{-6}$ & $1.72 \times 10^{-6}$ \\
biomass to bacteria & 99.0 & 2.8 & 0.46 \\
\hline
\end{tabular}

Table 4. Estimated carbon biomass (in $\mathrm{g}$ ) of thraustochytrids and bacteria $\mathrm{l}^{-1}$ at locations with high thraustochytrid abundance, at 200 to $2000 \mathrm{~m}$ in the Arabian Sea, assuming an average size of a thraustochytrid cell as $5.0 \mu \mathrm{m}$ with a carbon content of $20.6 \times 10^{-12}$ cell $^{-1}$. Bacterial carbon values based on values of $30.2 \times$ $10^{-15} \mathrm{~g}_{\text {carbon }}$ cell ${ }^{-1}$

\begin{tabular}{|lccc|}
\hline & $\begin{array}{c}\text { September/ } \\
\text { October 1993; } \\
\text { Stn 4b; } 1750 \mathrm{~m}\end{array}$ & $\begin{array}{c}\text { April/May 1994; } \\
\text { Stn 3a; } \\
1000 \mathrm{~m}\end{array}$ & $\begin{array}{c}\text { February/ } \\
\text { March 1995; } \\
\text { Stn 2a; 750 m }\end{array}$ \\
\hline $\begin{array}{l}\text { Maximum numbers } \\
\text { of thraustochytrids } \\
\text { (cells 1 }^{-1} \text { ) }\end{array}$ & $0.036 \times 10^{6}$ & $0.066 \times 10^{6}$ & $0.038 \times 10^{6}$ \\
$\begin{array}{l}\text { Maximum numbers } \\
\text { of bacteria } \\
\text { (cells 1 }{ }^{-1} \text { ) }\end{array}$ & $0.06 \times 10^{9}$ & $0.08 \times 10^{9}$ & $0.074 \times 10^{9}$ \\
$\begin{array}{l}\text { Maximum biomass } \\
\text { of thraustochytrids } \\
\begin{array}{l}\text { Maximum biomass } \\
\text { of bacteria }\end{array}\end{array}$ & $0.74 \times 10^{-6}$ & $1.36 \times 10^{-6}$ & $0.77 \times 10^{-6}$ \\
$\begin{array}{l}\text { Bacteria:thraustochytrid } \\
\text { biomass } \\
\% \text { of thraustochytrid } \\
\text { biomass to bacteria }\end{array}$ & 2.45 & $2.42 \times 10^{-6}$ & $2.23 \times 10^{-6}$ \\
\hline
\end{tabular}

locations, these values point out to the tremendous potential importance of these protists in mineralization processes and in the food web. Thraustochytrids also formed a significant component below $200 \mathrm{~m}$ and comprised 34.5 to $56 \%$ of bacterial carbon biomass in diferent seasons.

It is even more relevant to interpret the importance of thraustochytrids in the water columns in terms of their specific spatial and functional niches, than their overall biomass contribution in the water column per se relative to bacteria. It is evident from this study that thraustochytrids may have a direct relationship with POC at least in certain seasons (at the end of the winter monsoon in 1995, but not the pre-monsoon period of 1994; Fig. 5). Organic particles, such as the TEPs might be intense sites of thraustochytrid activities, while the rest of the water column might be impoverished in their population. The problems that need to be addressed in future are: (1) What is the biological source of particles that serve as their major nutritional source? For example, Raghukumar \& Raghukumar (1999) estimated thraustochytrid biovolumes were twice those of bacteria during certain stages of decomposition of salp faecal pellets in the Northern Arabian Sea. (2) Which biochemical component of the pot pourri of organic compounds present in the particles are they more efficient in breaking down compared to bacteria? TEPs, often a large fraction of POC were quantified during the summer monsoon of August 1996 (Kumar et al. 1998, Ramaiah et al. 2000). These authors have shown a substantial availability of labile carbon in the form of TEPs in the intermediate and deep waters of the Arabian Sea. This could partially satisfy the nutritional needs of thraustochytrids. (3) Do thraustochytrids, by virtue of their high nutritional value and relatively larger sizes benefit the mesozooplankton in the deeper waters as nutrition?

In view of the fairly large abundance of thraustochytrids in the water column, these questions need to be addressed in detail to understand their role in microbial dynamics. 
Acknowledgements. The authors are grateful to the Department of Ocean Development, Govt of India, for funding the India JGOFS programme, under which this work was carried out. This is NIO Contribution No. 3666

\section{LITERATURE CITED}

Anonymous (1981) Standard methods for the examination of water and wastewater. American Public Health Association, Washington, DC

Azam F, Steward GF, Smith DC, Ducklow HW (1994) Significance of bacteria in carbon fluxes in the Arabian Sea. Proc Indian Acad Sci (Earth Planet Sci) 103:341-351

Bahnweg G (1970a) Studies on the physiology of Thraustochytriales. I. Growth requirements and nitrogen nutrition of Thraustochytrium spp., Schizochytrium spp., Japonochytrium sp., Ulkenia spp. and Labyrinthuloides spp. Veröff Inst Meeresforsch Bremerhav 17:248-268

Bahnweg G (1970b) Studies on the physiology of Thraustochytriales. II. Carbon nutrition of Thraustochytrium spp., Schizochytrium spp., Japonochytrium sp., Ulkenia spp. and Labyrinthuloides spp. Veröff Inst Meeresforsch Bremerh 17:269-273

Bhattathiri PMA, Pant A, Sawant S, Gauns M, Matondkar SGP, Mohanraju R (1996) Phytoplankton production and chlorophyll distribution in the eastern and central Arabian Sea in 1994-1995. Curr Sci 71:857-862

Bremer GB, Talbot G (1995) Cellulolytic enzyme activity in the marine protist Schizochytrium aggregatum. Bot Mar 38:37-41

Burkill PH, Mantoura RFC, Owens NJP (1993) Biogeochemical cycling in the northwestern Indian Ocean: a brief overview. Deep-Sea Res 40:643-649

Cavalier-Smith T, Allsopp MTEP, Chao EE (1994) Thraustochytrids are chromists, not Fungi: 18s rRNA signatures of Heterokonta. Phil Trans R Soc Lond B 346:387-397

Ducklow H (1993) Bacterioplankton distributions and production in the northwestern Indian Ocean and Gulf of Oman, September 1986. Deep-Sea Res 40:753-771

Findlay RH, Fell JW, Coleman NK Vestal JT (1986) Biochemical indicators of the role of fungi and thraustochytrids in mangrove detrital systems. In: Moss ST (ed) The biology of marine fungi. Cambridge University Press, Cambridge, p 91-103

Fukuda R, Ogawa H, Nagata T, Koike I (1998) Direct determination of carbon and nitrogen contents of natural bacterial assemblages in marine environments. Appl Environ Microbiol 64:3352-3358

Gaertner A (1968) Eine Methode des quantitativen Nachweises niederer mit Pollen koederbarer Pilze im Meerwasser und im Sediment. Veröff Inst Meeresforsch Bremerhav 3:75-92

Gaertner A (1981) Some fungal parasites found in the diatom populations of the Rosfjord area (South Norway) during March 1979. Veröff Inst Meeresforsch Bremerhav 18: 29-33

Gaertner A (1982) Lower marine fungi from the northwest African upwelling areas and from the Atlantic off Portugal. Meteor Forschergeb Reihe D Biol 34:9-30

Gaertner A, Raghukumar S (1980) Ecology of thraustochytrids (lower marine fungi) in the Fladen Ground and other parts of the North Sea. I. 'Meteor' Forsch Ergebn A 22:165-185

Hansell DA, Peltzer ET (1998) Spatial and temporal variations of total organic carbon in the Arabian Sea. Deep-Sea Res II 45:2171-2193
Harrison KE (1990) The role of nutrition in maturation, reproduction and embryonic development of decapod crustaceans: a review. J Shellfish Res 9:1-28

Kimura H, Fukura T, Naganuma T (1999) Biomass of thraustochytrid protoctists in coastal water. Mar Ecol Prog Ser 189:27-33

Kumar MD, Rajendran A, Somasundar K, Haake B, Jenisch A, Shuo Z, Ittekot V, Desai BN (1990) Dynamics of dissolved organic carbon in the northwestern Indian Ocean. Mar Chem 31:299-316

Kumar MD, Sarma VVSS, Ramaiah N, Gauns M, De Sousa SN (1998) Biogeochemical significance of transparent exopolymer particles in the Indian Ocean. Geophys Res Lett 25:81-84

Madhupratap M, Parulekar AH (1993) Biological processes of the northern Indian Ocean. In: Ittekkot V, Nair RR (eds) Monsoon biogeochemistry. Mitt Geol Palönt Inst, University of Hamburg

Madhupratap M, Gopalakrishnan TC, Haridas P, Nair KKC, Aravindakshan PN, Padmavati G, Paul S (1996) Lack of seasonal and geographic variation in mesozooplankton biomass in the Arabian Sea and its structure in the mixed layer. Curr Sci 71:863-868

Miller JD, Jones EBG (1983) Observations on the association of thraustochytrid marine fungi with decaying seaweed. Bot Mar 26:345-351

Morrison JM, Codispoti LA, Gaurin S, Jones B, Manghnani V, Zheng Z (1998) Seasonal variation of hydrographic and nutrient fields during the US JGOFS Arabian Sea process study. Deep-Sea Res II 45:2053-2101

Moss ST (1986) Biology and physiology of the Labyrinthulales and Thraustochytriales In: Moss ST (ed) The biology of marine fungi. Cambridge University Press, Cambridge, p 105-129

Naganuma T, Takasugi H, Kimura H (1998) Abundance of thraustochytrids in coastal plankton. Mar Ecol Prog Ser 162:105-110

Naqvi SWA (1991) Geographical extent of denitrification in the Arabian Sea in relation to some physical processes. Oceanolog Acta 14:281-290

Naqvi SWA (1994) Denitrification processes in the Arabian Sea. Proc Indian Acad Sci (Earth Planet Sci) 103:279-300

Naqvi SWA, Kumar MD, Narvekar PV, De Sousa SN, George MD, D'Silva C (1993) An intermediate nepheloid layer associated with high microbial metabolic rates and denitrification in the northwest Indian Ocean. J Geophys Res 98:16469-16479

Parsons TR, Maita Y, Lalli CM (1984) A manual of chemical and biological methods for seawater analysis. Pergamon Press, London

Porter D (1990) Labyrinthulomycota. In: Margulis L, Corliss JO, Melkonian M, Chapman D (eds) Handbook of Protoctista. Jones and Bartlett, Boston, MA, p 388-398

Prasanna Kumar S, Prasad TG (1996) Winter cooling in the northern Arabian Sea. Curr Sci 71:834-841

Raghukumar C, Nagarkar S, Raghukumar S (1992) Association of thraustochytrids and fungi with living marine algae. Mycol Res 96:542-546

Raghukumar S (1992) Bacterivory: a novel dual role for thraustochytrids in the sea. Mar Biol 113:165-169

Raghukumar S (1996) Morphology, taxonomy and ecology of thraustochytrids and labyrinthulids, the marine counterparts of zoosporic fungi. In: R Dayal (ed) Advances in zoosporic fungi. M.D. Publications Pvt. Ltd, New Delhi, p 35-38

Raghukumar S, Gaertner A (1980) Ecology of the thraustochytrids (lower marine fungi) in the Fladen Ground and 
other parts of the North Sea. II. Veröff Inst Meeresforsch Bremerh 18:289-308

Raghukumar S, Raghukumar C (1999) Thraustochytrid fungoid protists in faecal pellets of the tunicate Pegea confoederata, their tolerance to deep-sea conditions and implication in degradation processes. Mar Ecol Prog Ser 190:133-140

Raghukumar S, Schaumann K (1993) An epifluorescence microscopy method for direct detection of the fungi-like marine protists, the thraustochytrids. Limnol Oceanogr 38:182-187

Raghukumar S, Raghukumar C, Rajendran A (1990) Abundance of thraustochytrid fungi in the Arabian Sea. Estuar Coast Shelf Sci 31:351-358

Raghukumar S, Sharma S, Raghukumar C, Sathe-Pathak V, Chandramohan D (1994) Thraustochytrid and fungal component of marine detritus. IV. Laboratory studies on decomposition of leaves of the mangrove Rhizophora apiculata Blume. J Exp Mar Biol Ecol 183:113-131

Ramaiah N, Raghukumar S, Gauns M (1996) Bacterial abun-

Editorial responsibility: Karin Lochte, Kiel, Germany dance and production in the central and eastern Arabian Sea. Curr Sci 71:878-882

Ramiah N, Sarma VVSS, Gauns M, Kumer MD, Madhupratap M (2000) Abundance and relationship of bacteria with transparent exopolymer particles during the 1996 summer monsoon in the Arabian Sea. Proc Indian Acad Sci (Earth Planet Sci) 109:443-451

Sarma VVSS, Kumar MD, George MD, Rajendran A (1996) Seasonal variations in inorganic carbon components in the central and eastern Arabian Sea. Curr Sci 71:852-856

Sarma VVSS, Kumar MD, George MD (1999) The central and eastern Arabian Sea as a perennial source of atmospheric carbon dioxide. Tellus 50B:179-184

Shetye SR, Gouveia AD, Shenoi SSC (1994) Circulation and water masses of the Arabian Sea. Proc Indian Acad Sci (Earth Planet Sci) 103:107-123

Smith S, Roman M, Prusova I, Wishner K, Gowing M, Codispoti LA, Barber R, Mana J, Flagg C (1998) Seasonal response of zooplankton to monsoonal reversals in the Arabian Sea. Deep-Sea Res 45:1369-1403

Submitted: May 15, 2000; Accepted: March 7, 2001

Proofs received from author(s): May 9, 2001 